\title{
ELEMENTI OBMEJNOSTI IN FAKTORJI OBLIKOVANJA PREKOMEJNIH OBMOČIJ NA PRIMERU SLOVENIJE
}

\author{
Milan Bufon*
}

Izvleček

UDK 911.3(497.12-04)

Clanek na primeru Slovenije obravnava nekatere elemente obmejnosti ter faktorje oblikovanja prekomejnih območij, s posebnim poudarkom na različni predispoziciji konsolidiranih in novejših obmejnih območij do prekomejnega sodelovanja ter na vlogi kulturne afinitete obmejnega prebivalstva pri oblikovanju prekomejnih območij.

Ključne besede: Obmejna območja, obmejne skupnosti, prekomejna povezanost

\section{Abstract}

UDC 911.3(497.12-04)

ELEMENTS OF BORDERNESS AND FACTORS OF EVOLUTION OF TRANSBORDER REGIONS: THE CASE OF SLOVENIA

The article deals with some elements of border landscapes and factors of transformation of this areas into transborder regions. On the case of Slovenia differences between consolidated and recent border areas in terms of transborder relations and the role of cultural affinity of the border population in developing transborder regions are then discussed.

Key worsds: Border areas, border communities, transborder relations

\section{OBMEJNA OBMOČJA IN PROCESI V OBMEJNIH OBMOČJIH}

Morda je nekoliko presenetljivo dejstvo, da v svetovni literaturi kljub nekaterim poizkusom (Rumley in Minghi, 1991) pravzaprav ni zaslediti nobene uspešne tipizacije obmejnih območij. To je sicer razumljivo, če pomislimo, da so si ta območja v bistvu tudi zelo različna. Njihov položaj pogojujejo $\mathrm{v}$ glavnem pretekli in aktualni družbeni faktorji, se pravi elementi, procesi in pojavi s področja zgodovinske izkušnje in spomina ter sedanjih socialnih, političnih in kulturnih odnosov $\mathrm{v}$ okviru posameznih državnih sistemov in v meddržavnih odnosih.

V Evropi lahko, če stvari močno poenostavimo, v genetskem pogledu razlikujemo med dvema glavnima tipoma obmejnih območij: prvi tip predstavljajo konsolidirana obmejna območja, kjer potek mejne črte že nekaj stoletij ni doživel izrazitejših sprememb, drugi tip pa recentna obmejna območja, ki so nastala zaradi novejših, povečini po prvi in drugi svetovni vojni začrtanih meja med novonastalimi, a tudi že obstoječimi državami. $\mathrm{V}$ to kategorijo bi lahko kot poseben tip vključili še "nova" obmejna območja, ki so v

\footnotetext{
* Mag., Slovenski raziskovalni inštitut, ul.Carducci 8, 34122 Trst-Trieste, Italija
} 
Srednji in Vzhodni Evropi nastala v zadnjih letih po razpadu nekaterih večnacionalnih socialističnih držav. Kot splošen modifikator obeh navedenih osnovnih kategorij obmejnih območij se javlja stopnja strukturne odprtosti med sosednjima državama, na katero so zlasti v tem stoletju odločilno vplivali ideološki faktorji.

V grobem bi lahko rekli, da so razlike med obema omenjenima kategorijama glede na intenzivnost prekomejnega komuniciranja, če za trenutek odmislimo ideološki modifikator, te, da so "stara" obmejna območja na splošno manj dovzetna za prekomejno integracijo kot "nova" (Bufon, 1992a). Trditev je navidez protislovna, saj vsi vemo, kakšne konflikte je povzročala $v$ nedavnem, zlasti povojnem obdobju razmejitev nekdaj homogenih upravnih, družbenih, ekonomskih in kulturnih regij med dve ali celo več držav. Toda pomisliti moramo tudi, da potekajo "stare" meje, naslanjajoč se na "stare" razmejitvene koncepte, večinoma po "naravnih", zlasti orografskih linijah v pretežno hribovitem ali manj poseljenem svetu, medtem ko so se "nove" meje največkrat zarezale $v$ že urbanizirana in gosteje poseljena območja, v katerih je prebivalstvo med seboj intenzivno komuniciralo. In prav to njihovo preteklo skupno življenje omogoča sedanjim obmejnim skupnostim, kjer le obstajajo vsaj minimalne možnosti prekomejne interakcije, da med seboj sodelujejo in stem obmejni prostor aktivno integrirajo. Tega obmejne skupnosti ob tradicionalnih "starih" mejah ne počenjajo, ker so vajene ločenega življenja in se vključujejo le v lastne državne sisteme.

V bistvu gre tu za dolgotrajne prostorske identifikacijske procese, a tudi za kompenzacijo izgubljenega ravnotežja ob razmejitvi. Na nek način bi lahko rekli, da se to, kar je takoj po razmejitvi homogenih, historičnih regij predstavljalo za obmejno prebivalstvo pravo tragedijo, sčasoma izkaže kot precejšnja prednost pri kasnejšem integriranju obmejnih območij, seveda v pogojih kolikor toliko "normalne" prekomejne komunikacije. In prekomejna integracija obmejnih območij je danes pravzaprav tisti proces, za katerega si v Zahodni in Srednji Evropi tendenčno vsi prizadevajo. Toda kaj so v resnici "obmejna območja"? Najbolj enostavna je trditev, da so ta območja poseben tip perifernih regij, $\mathrm{v}$ katerih je gospodarsko in družbeno življenje neposredno pod vplivom bližine mednarodne meje. To so torej relativno kompleksni prostori, katere lahko neredko, zaradi visoke stopnje medsebojne povezanosti, komplementarnosti in integriranosti, upravičeno opredeljujemo s terminom "obmejna regija" (Klemenčič, 1987). Seveda pa so tudi v takih okvirih možne različne interpretacije: nekateri proučevalci izpostavljajo pri tem zlasti infrastrukturne, makroekonomske aspekte prekomejnega povezovanja, drugi pa poudarjajo pomen "drobnih" prekomejnih stikov na mikroekonomskem, družbenem in kulturnem področju. Pri tem je značilno, da ti stiki v celoti izhajajo iz prostorske mobilnosti obmejnega prebivalstva pri zadovoljevanju svojih rednih potreb po oskrbi, delu, preživljanju prostega časa in celo izobraževanju, a tudi po vzdrževanju tistih medosebnih vezi, ki so mnogokrat podobni samemu pojavu meje. Na tej osnovi pa je možno ugotoviti ne le stopnjo kulturne, socialne in ekonomske integracije obmejnih regij, temveč je mogoče tudi zelo podrobno analizirati strukturo prekomejnih stikov, ki se na ta način zelo dobro prilagajajo običajnim družbenim vedenjskim vzorcem, kakršne je odkrivala in razvijala 
na primer nemška socialno-geografska raziskovalna metoda $\mathrm{v}$ okviru kategorij "bivanja" in "življenja v skupnosti", "dela", "oskrbe", "izobraževanja" in "preživljanja prostega časa", in katero je slovenska geografija pri proučevanju prekomejne povezanosti prvič uporabila že v začetku sedemdesetih let (Jeršič in Klemenčič, 1973).

Definirati obmejno regijo le kot "pokrajino, katere del je meja" (Prescott, 1987, str.159) zato ni dovolj. Prav tako ni dovolj, če obmejno regijo pojmujemo le kot skupek dveh oddeljenih obmejnih območij (Guichonnet in Raffestin, 1974), ne da bi upoštevali njuno prekomejno povezovalno vlogo. Jasno je, da obmejna regija ne more predstavljati docela homogene enote, saj prinaša že sam pojav meje osnovno diskontinuiteto $\mathrm{v}$ takem prostoru, ampak da gre iskati povezanost te regije predvsem $\mathrm{v}$ funkcionalnih odnosih med obmejnima območjema. Ti odnosi pa se mnogokrat razvijajo ravno zaradi obstoja nekaterih disparitet, zlasti ekonomske narave, a tudi nekaterih afinitet, zlasti kulturne narave, med enim in drugim obmejnim območjem. Obmejna regija je torej "regija" po principu funkcionalnosti glede na obstoječa nesorazmerja in prilagajanja obmejnega prebivalstva tem različnostim v okviru nekega "polja napetosti" (Leimgruber, 1987). Hkrati pa je taka tudi po principu homogenosti, saj obe obmejni območji velikokrat združuje pripadnost isti kulturni pokrajini, obmejno prebivalstvo pa označujejo iste kulturne karakteristike (Jeanneret, 1985).

Poleg navedenih terminoloških problemov se poraja še vprašanje same razmejitve obmejnih območij. Čeprav razni mednarodni akti ob sprejetju dvostranskih sporazumov o urejanju prekomejnega pretoka blaga in oseb obseg takih območij, za katera so predvidene posebne olajšave, večinoma določajo v širini do 25 kilometrov od mejne črte (Ercmann, 1987), pa je dejanski obseg obmejne regije lahko precej drugačen, a zlasti veliko bolj diferenciran. Kjer med obmejnima območjema obstajajo pogoji kulturne afinitete, predstavlja seveda obseg tega prostora osnovno jedro prekomejnih regij, sicer pa so meje teh regij močno različne glede na uporabljen indikator prekomejne povezanosti, saj nanje vplivajo najrazličnejši faktorji: od same administrativne strukture obmejnih območij do prometnih, demografskih, ekonomskih, a tudi kulturnih, historičnih ter "objektivnih" fizičnih dejavnikov.

Posebno značilno je na primer, da drobne ekonomske transakcije na področju oskrbe, dela in preživljanja prostega časa izhajajo bolj iz trenutnih neravnovesij $v$ valutnih tečajih, stopnjah inflacije in kupni moči med obmejnima območjema, kakor pa iz kake trajnejše predispozicije posameznih obmejnih območij za zadovoljevanje in razvijanje te ali one prostorsko relevantne dejavnosti. Vse te prekomejne transakcije so zato dokaj nestabilne in vodijo interesente zdaj na eno, spet drugič pa na drugo stran meje. Povsem drugače pa je s kulturnimi in drugimi osnovnimi družbenimi stiki, ki izvirajo iz potrebe obmejnega prebivalstva po ohranjanju tradicionalnih vezi v okviru njihovega skupnega kulturnega prostora in se zato odlikujejo po svoji stabilnosti in trdoživosti tudi v primeru manj odprtih mejnih režimov (Suarez-Villa et al., 1992). 
Elementi obmejnosti in faktorji...

\section{SLOVENSKA OBMEJNA OBMOČJA IN SLOVENSKA GEOGRAFIJA OBMEJNOSTI}

Glede na omejen teritorialni obseg Slovenije, njeno pomembno tranzitno prometno funkcijo in dejstvo, da nezanemarljiv delež Slovencev živi izven njenih državnih meja v sosednjih obmejnih območjih Italije, Avstrije in Madžarske, je razumljivo, da je tematika obmejnosti že dalj časa prisotna $\mathrm{v}$ slovenski geografiji. Pravzaprav lahko celotno Slovenijo, še zlasti po njeni osamosvojitvi, opredelimo kot obmejno deželo, saj slovenska prestolnica - Ljubljana - v povprečju ni oddaljena več kot 100 kilometrov od mednarodnih meja. (Klemenčič in Genorio, 1992).

Slovenska obmejna območja imajo seveda različen historiat in obstojnost: nekateri obmejni predeli so se izoblikovali že takoj ob formiranju teritorialnih držav na tem območju v 16.stoletju, $v$ nekaterih je državna meja recentnejša, a sloni na dolgotrajni administrativni meji (tak primer je $\mathrm{v}$ bistvu tudi nova slovensko-hrvaška meja), spet drugje pa je meja povsem nanovo prerezala zelo obstojne administrativne enote (na primer Goriško in Štajersko). Poleg tega pa lahko slovenska obmejna območja delimo še po njihovih fizičnogeografskih lastnosti, doseženi stopnji urbanizacije ter socioekonomskega razvoja in odgovarjajoči prehodnosti do sosednjih obmejnih območij, oziroma po intenzivnosti prekomejnega pretoka oseb, blaga in informacij, a tudi po vplivu, ki jo ima bližina meje na družbeno strukturo, razvoj in zunanji izgled obmejnih območij (Klemenčič in Bufon, 1993).

Posebno pozornost je, zlasti $\mathrm{v}$ 80.letih, slovenska geografija posvetila funkcijskim aspektom prekomejne povezanosti. V tem okviru izstopa še posebej južni, urbaniziran del sedanje slovensko-italijanske meje $\mathrm{v}$ okolici Trsta in Gorice, kjer je prišlo do oblikovanja prave obmejne regije (Klemenčič in Bufon, 1991). Velika intenzivnost prekomejnih stikov in izmenjav je tu, bolj kot od močnih mednarodnih tranzitnih tokov, posledica lokalnih dejavnikov na področju dnevne migracije delovne sile, nakupov, rekreacije ter drugih motivacij redne prekomejne izmenjave (Bufon, 1993a). Upoštevati gre nadalje, da $v$ celotnem obmejnem pasu $v$ Italiji, zlasti pa $v$ obeh navedenih centrih, živi dokaj številna slovenska manjšina, medtem ko je v južnem obmejnem območju, ki obsega poleg slovenskega še hrvaški del Istre, prisotna, čeprav v manjšem obsegu, italijanska manjšina. Precejšen delež prekomejnih stikov pa v tržaško-istrski obmejni regiji vzdržujejo tudi številne osebe, ki so iz političnih in ekonomskih vzrokov po zadnji vojni zapustile Istro in se naselile $v$ Trstu (Bufon, 1993b). Nekatere analize prekomejnih lokalnih stikov na sedanjem slovensko-italijanskem obmejnem območju, kot jih je registriral dnevni tisk (Sussi, 1973; Delli Zotti, 1982), kažejo ne le na njihovo številčno rast, ampak tudi na vlogo nacionalnih manjšin pri njihovem spodbujanju in vzdrževanju. Značilno je tako, da so se lokalni politični prekomejni stiki okrepili le konec 60 .let na osnovi predhodnih kulturnih in ekonomskih izmenjav med obmejnim prebivalstvom. Sicer pa je te izmenjave, v želji, da bi se izognili "berlinizaciji" obmejnih območij okrog Trsta in Gorice, ki pred tem niso bila nikdar ločena s politično mejo, predvidel že mirovni sporazum iz leta 1947. 
Na ta način so bili že po dveh letih odprti številni dvolastniški in nekaj mednarodnih prehodov, obmejni promet pa je docela sprostil sporazum iz leta 1955, ki je obmejnemu prebivalstvu znotraj 10-kilometrskega obmejnega pasu zagotovil vrsto ugodnosti pri mejnem prehajanju in prenosu blaga, uredil pa je tudi regionalno trgovinsko izmenjavo. $\mathrm{Na}$ ta način se je $\mathrm{v}$ tem obmejnem območju, kljub velikim razlikam med družbenopolitičnima sistemoma sosednjih držav, a zaradi kulturne sorodnosti obmejnega prebivalstva in dolgotrajnih medsebojnih družbenih in gospodarskih vezi, že zelo zgodaj razvilo prekomejno sodelovanje, kakršnega niso poznala niti druga, družbeno razvitejša obmejna območja Zahodne in Srednje Evrope (glej karti 1 in 2). Še danes ostaja to sodelovanje med vsemi italijanskimi in slovenskimi obmejnimi območji tu najbolj intenzivno in kapilarno, pričakovati pa je, da se bo $\mathrm{v}$ to prekomejno regijo $\mathrm{z}$ ureditvijo meddržavnih odnosov med Slovenijo in Hrvaško ter med Italijo in Hrvaško, v večji meri vključil še severni del Istre.

Slika 1: Funkcijska struktura obmejnega prebivalstva pri izpolnjevanju nekaterih prekomejnih dejavnosti

Functional structure of the Girizia transborder area considering motivarions for commuting among the border population

Italijansko obmejno območje Slovensko obmejno območje

Italian border zone Slovene border zone

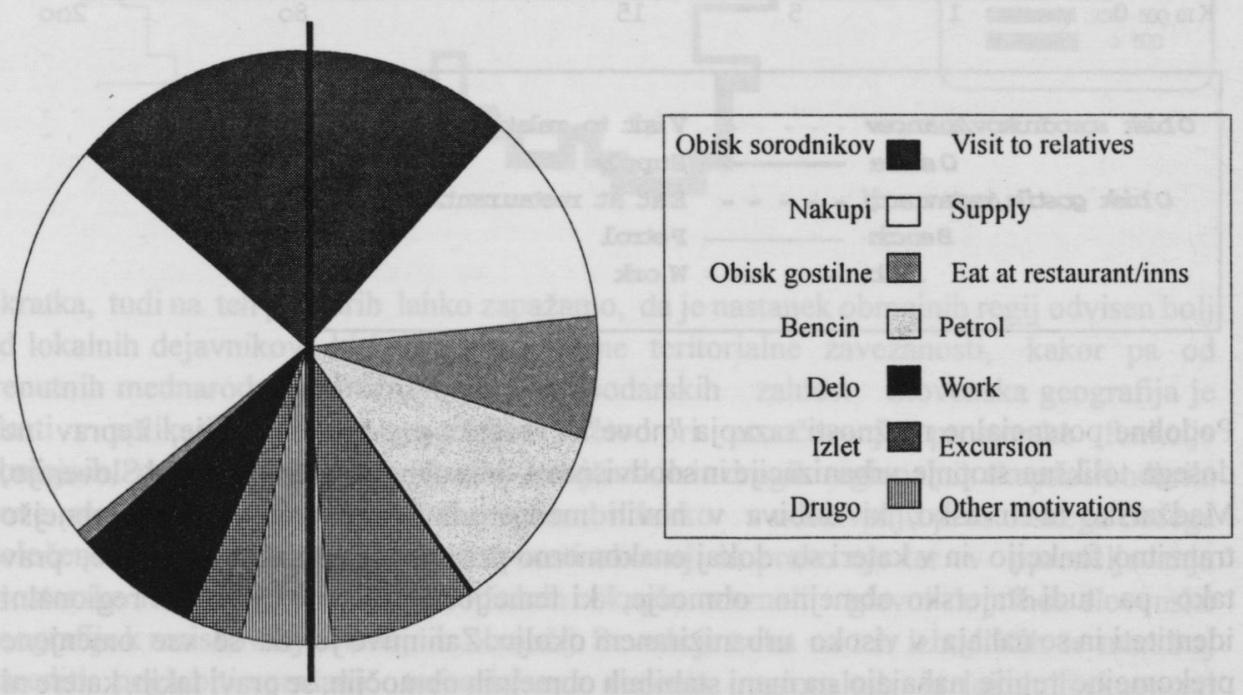


Slika 2: Akcijski radij obmejnega prebivalstva pri izpolnjevanju nekaterih prekomejnih dejavnosti

The range of action of the border population during fulfilment of some transborder activities
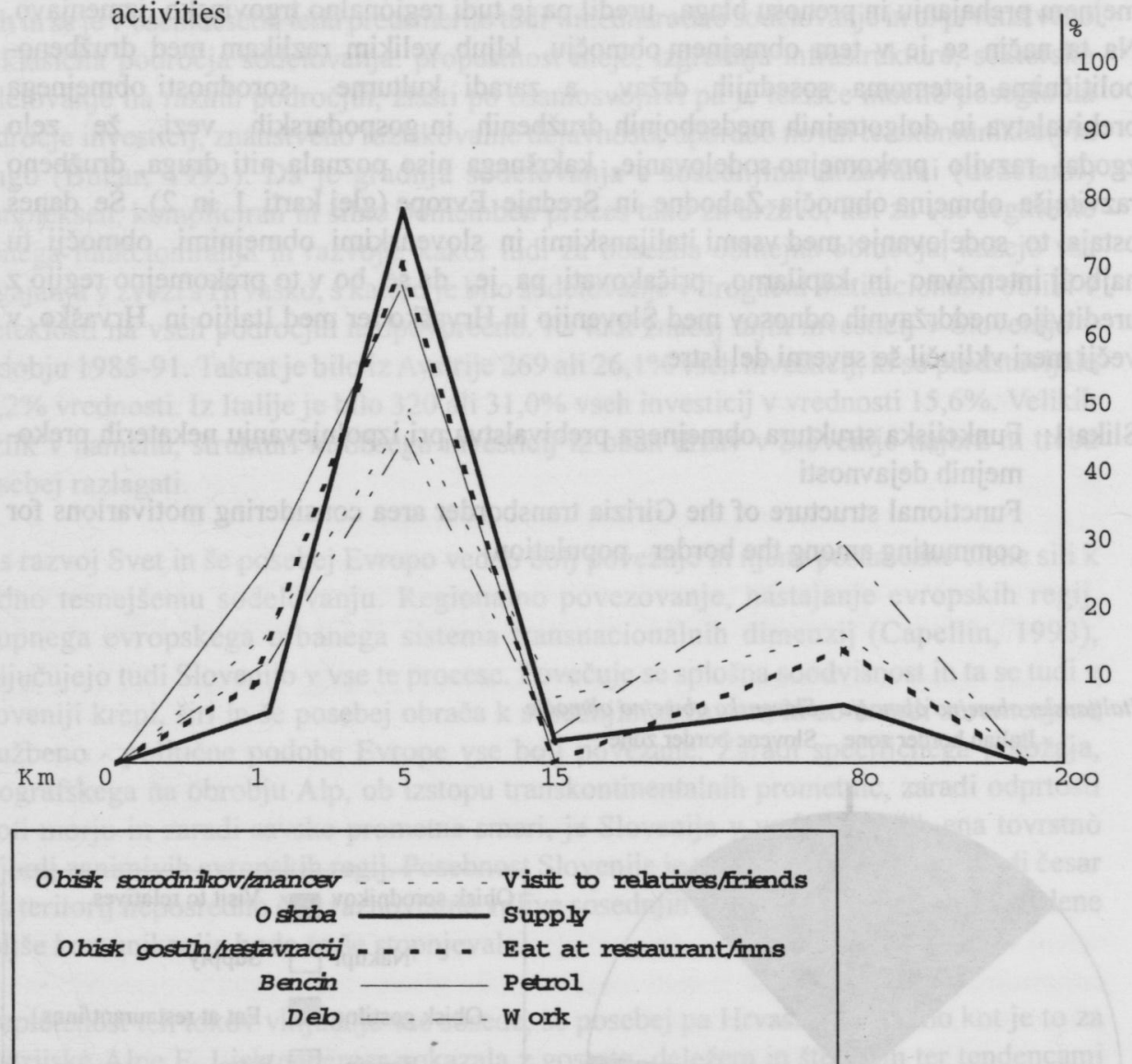

Podobne potencialne možnosti razvoja "nove" evropske prekomejne regije, čeprav ne dosega tolikšne stopnje urbanizacije in soodvisnosti, ima obmejno območje med Slovenijo, Madžarsko in Hrvaško, ki dobiva $v$ novih mednarodnih razmerah vse pomembnejšo tranzitno funkcijo in v kateri so dokaj enakomerno prisotne nacionalne manjšine, prav tako pa tudi štajersko obmejno območje, ki temelji na skupni historični regionalni identiteti in se nahaja $v$ visoko urbaniziranem okolju. Zanimivo je, da se vse omenjene prekomejne regije nahajajo na manj stabilnih obmejnih območjih, se pravi takih, katere ni oblikoval trajnejši potek mednarodne meje, ampak je temu nasprotno lahko zaznamovalo celo njeno pogosto spreminjanje. Ni slučaj zato, če so taka obmejna območja obenem mnogokrat etnično pomešana in je $\mathrm{v}$ njih prisotna za prekomejno sodelovanje zelo 
Elementi obmejnosti in faktorji...

pomembna skupna kulturna podlaga. V primerih historično stabilnejših meja, kakršne lahko zapazimo $\mathrm{v}$ severnem delu slovensko-italijanske, ob zahodnem delu avstrijskoslovenske in v osrednjem delu slovensko-hrvaške meje, pa je pričakovati, da bo nad lokalnim prevladal tranzitni promet, ki bo lahko sicer zelo intenziven, a zaradi svoje izrazito linearne naravnanosti preko nekaterih mejnih točk ne bo mogel oblikovati sklenjenih obmejnih regij (glej karti 3 in 4).

Slika 3: Obstojnost sedanjih političnih meja Slovenije

Duration of the current political boundaries of Slovenia

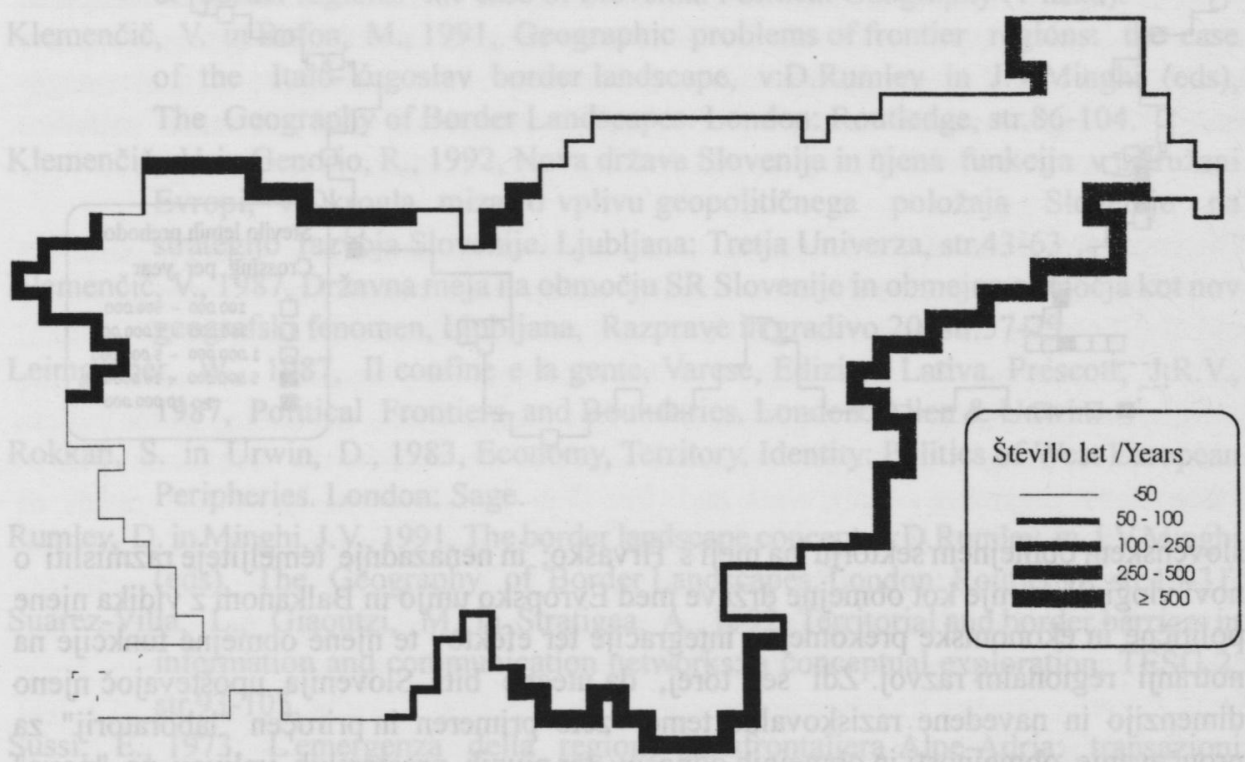

Skratka, tudi na teh primerih lahko zapažamo, da je nastanek obmejnih regij odvisen bolj od lokalnih dejavnikov, ki izvirajo iz skupne teritorialne zavezanosti, kakor pa od trenutnih mednarodno-političnih in gospodarskih zahtev. Slovenska geografija je zlasti $\mathrm{v}$ aplikaciji socialno-geografskih metod pri proučevanju prostorske funkcije obmejnih, predvsem etničnih, narodno-manjšinskih in drugih regionalnih skupnosti odkrila nove raziskovalne dimenzije. Dejansko bi lahko v odkrivanju prostorskega obsega določenih relevantnih družbenih aktivnosti ob meji in preko nje ter $\mathbf{v}$ opredeljevanju prostorske funkcije obmejnih socialnih skupin zaznali glavni doprinos slovenske geografije k raziskovanju obmejnih območij. Seveda je treba na teh izhodiščih še marsikaj narediti: poglobiti vprašanje teritorialnega vedenja regionalnih in lokalnih skupnosti ob meji ter njihove kulturne in historične identitete; razširiti raziskovalni interes od funkcionalno bolj povezanih tudi na ostala obmejna območja in odkrivati vzroke slabše prekomejne interakcije; sistematizirati raziskovalno delo na najnovejšem in najdaljšem 
Slika 4: Prehodnost sedanjih političnih meja Slovenije

Permeability of the current political boundaries of Slovenia

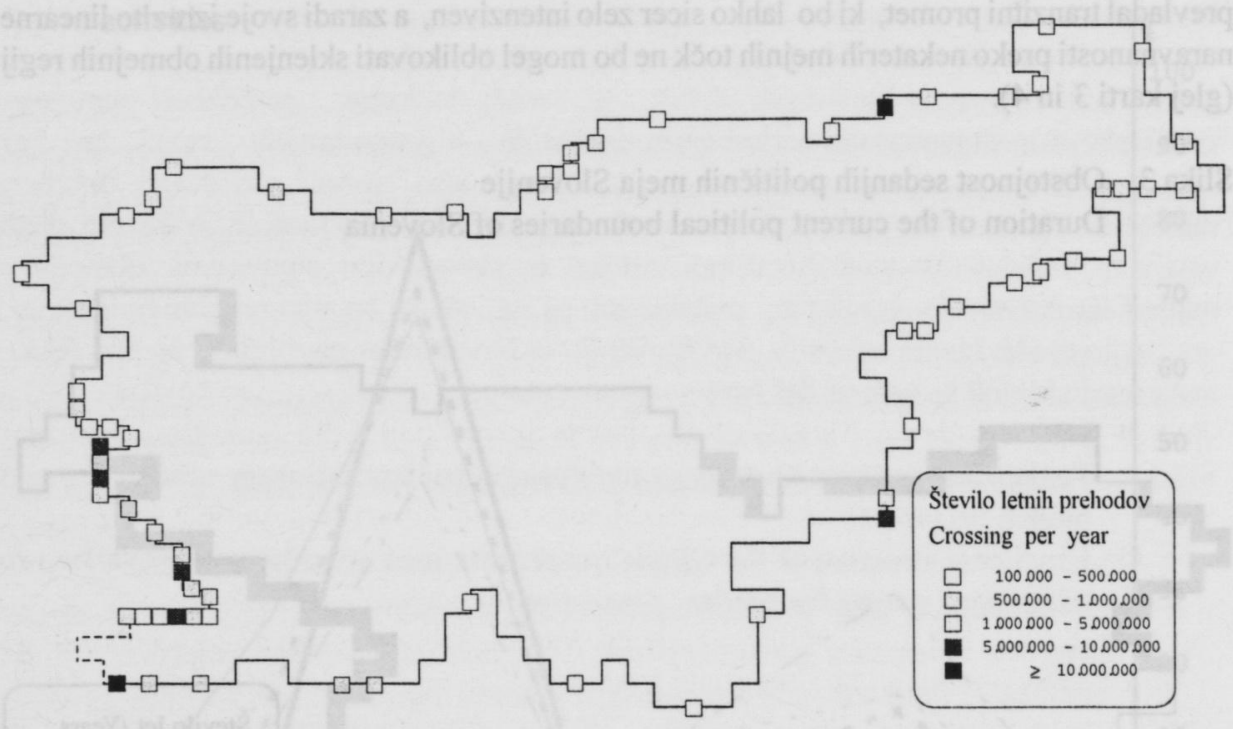

slovenskem obmejnem sektorju na meji s Hrvaško; in nenazadnje temeljiteje razmisliti o novi vlogi Slovenije kot obmejne države med Evropsko unijo in Balkanom z vidika njene politične in ekonomske prekomejne integracije ter efektov te njene obmejne funkcije na notranji regionalni razvoj. Zdi se, torej, da utegne biti Slovenija, upoštevajoč njeno dimenzijo in navedene raziskovalne teme, zelo primeren in priročen "laboratorij" za proučevanje obmejnosti in obmejnih odnosov ter njunih prostorskih vplivov na "nova" in "stara" obmejna območja Srednje Evrope.

\section{LITERATURA}

Bufon, M., 1993a, Cultural and social dimensions of borderlands: the case of the ItaloSlovene transborder area. GeoJournal 30, str.235-240.

Bufon, M., 1993b, Istra: novi problemi starih regij. Annales ( $v$ tisku).

Bufon, M., 1992a, Geografija obmejnosti: da ali ne. Ljubljana, Geographica Slovenica 23, str.345-363.

Bufon, M., 1992b, Prostorska opredeljenost in narodna pripadnost. Trst: ZTT.

Delli Zotti, G., 1982, Transnational relations in a border region: the case of FriuliVenetia Julia, v:R.Strassoldo in G.Delli Zotti (eds), Cooperation and Conflict in Border Areas. Milano: Angeli, str.25-61. 
Ercmann, S., ed., 1987, Cross-Border Relations: European and North American Perspectives, Schweizer Studien zum Internationalen Recht/Etudes Suisses de Droit International, Band/Volume 49, Zu'rich, Schulters Polygraphischer Verlag.

Guichonnet, P. in Raffestin, C. (1974); Geographie des frontieres. Paris: Presses Universitaires de France.

Jeanneret, P., 1985, Regions et frontieres internationales. Neuchatel: EDES.

Jeršič, M. in Klemenčič, V., 1973, Topical problems of open boundaries: the case of Slovenia, v:R.Strassoldo (ed), Confini e regioni, Trieste, Lint, str.123-134.

Klemenčič, V. in Bufon, M., 1993, Cultural elements of integration and transformation of border regions: the case of Slovenia. Political Geography ( $v$ tisku).

Klemenčič, V. in Bufon, M., 1991, Geographic problems of frontier regions: the case of the Italo-Yugoslav border landscape, v:D.Rumley in J.V.Minghi (eds), The Geography of Border Landscapes. London: Routledge, str.86-104.

Klemenčič, V. in Genorio, R., 1992, Nova država Slovenija in njena funkcija v združeni Evropi, v:Okrogla miza o vplivu geopolitičnega položaja Slovenije na strategijo razvoja Slovenije. Ljubljana: Tretja Univerza, str.43-63.

Klemenčič, V., 1987, Državna meja na območju SR Slovenije in obmejna območja kot nov geografski fenomen, Ljubljana, Razprave in gradivo 20, str.57-79.

Leimgruber, W., 1987, Il confine e la gente, Varese, Edizioni Lativa. Prescott, J.R.V., 1987, Political Frontiers and Boundaries. London: Allen \& Unwin.

Rokkan, S. in Urwin, D., 1983, Economy, Territory, Identity: Politics of West European Peripheries. London: Sage.

Rumley, D. in Minghi, J.V., 1991, The border landscape concept, v:D.Rumley in J.V.Minghi (eds), The Geography of Border Landscapes. London: Routledge, str.15-31. Suarez-Villa, L., Giaoutzi, M. in Stratigea, A., 1992, Territorial and border barriers in information and communication networks: a conceptual exploration, TESG 2, str.93-105.

Sussi, E., 1973, L'emergenza della regione transfrontaliera Alpe-Adria: transazioni "pubbliche" tra Carinzia, Friuli-Venezia Giulia e Slovenia, v:Confini e regioni. Trieste: ISIG, str.135-146.

\section{ELEMENTS OF BORDERNESS AND FACTORS OF EVOLUTION OF TRANSBORDER REGIONS: THE CASE OF SLOVENIA}

\section{Summary}

Even though no satisfactory typification of borders and border landscapes has been produced so far, we may divide them into two major groups in terms of intensity of transborder relations: the 'old', consolidated borders and the 'new' ones. The first seem to be less susceptible to transborder communication than the other, considering that in many cases they have separated lasting social and economic regions. Paradoxically, where the greater were problems in the political partition of such homogeneous regions, the greater are then 
Elementi obmejnosti in faktorji...

opportunities for these 'new' border areas to develope, under more or less normal conditions of transborder communication, into integrated transborder regions. And transborder integration is clearly a process for which many endeavours have been made in Western and Central Europe. But what are 'transborder regions? We may define them as a special type of peripheral regions that are socially and economically influenced by the border and present a good level of transborder relations, complementarity and integration. Transborder relations can be measured, naturally, both in their 'macro' and 'micro' dimension, although the latter are considered to be much more fundamental. In fact, the intensity of local transborder relations provides not only the degree of cultural, social and economic integration between the two border areas, but also the structure and the spatial extension of the transborder regions. It is interesting to note that Slovene geographers have studied transborder relations in the framework of the social geographical categories of 'living in community', 'work', 'supply', 'education' and 'free-time activities since the seventies, discovering new dimensions in the analysis of border regions.

The implementation of field research methods has demonstrated, for example, that the extension of functional border areas actually varies considerably from border to border and also between different sectors of the same border. Where the condition of cultural affinity is present, the area subject to this condition may represent the core of the transborder region, otherwise the extension of this region differs depending on the indicator used to gauge transborder relations. Significantly, transborder economic microtransactions regarding supply, work and free-time activities are more the result of momentary disparities in terms of inflation or currency exchange rates than an expression of a durable predisposition of the two border areas to develope particular transborder activities. On the other hand, the stability of cultural and social transborder relations, that often root in the previous period in which the border population share a common territorial identity, makes transborder communication possible even in a situation of a less open boundary.

The Slovenian borders have developed in many different ways: some of them were established as soon as in the 16th Century, other - as in the case of the current boundary between Slovenia and Croatia - are very recent but they functioned as administrative boundaries in the previous period, other again has divided lasting administrative units. Despite this great variety of the Slovenian borders, only functional border regions have been studied in more depth, particularly the southern part of the current Italo-Slovene border landscape around Trieste and Gorizia. Investigations revealed that economic ties could develop only when local personal transborder contacts had been improved. These contacts were later followed by social contacts (sports, cultural) and only then political, which were strenghtened and 'normalized' as late as in the seventies. It seems that particularly knowledge of both languages and ethnic intertwining of the border population provide for more sophisticated and intense forms of social and cultural cooperation and integration. Here, not only international traffic is present, but also an elaborate system of local social, economic and cultural transborder interactions which provides the very 